\title{
Genetic analysis of aluminum tolerance in Brazilian barleys ${ }^{(1)}$
}

\author{
Euclydes Minella ${ }^{(2)}$ and Mark Earl Sorrells ${ }^{(3)}$
}

\begin{abstract}
Aluminum (Al) toxicity is a major factor limiting barley growth in acid soils, and genotypes with adequate level of tolerance are needed for improving barley adaptation in Brazil. To study the inheritance of Al tolerance in Brazilian barleys, cultivars Antarctica 1, BR 1 and FM 404 were crossed to sensitive Kearney and PFC 8026, and intercrossed. Parental, $\mathrm{F}_{1}, \mathrm{~F}_{2}$ and $\mathrm{F}_{6}$ generations were grown in nutrient solution containing $0.03,0.05$ and $0.07 \mathrm{mM}$ of $\mathrm{Al}$ and classified for tolerance by the root tip hematoxylin staining assay. Tolerant by sensitive $\mathrm{F}_{2}$ progenies segregated three tolerant to one sensitive, fitting the 3:1 ratio expected for a single gene. The $F_{6}$ populations segregated one tolerant to one sensitive also fitting a monogenic ratio. The $\mathrm{F}_{2}$ seedlings from crosses among tolerant genotypes scored the same as the parents. Since the population size used would allow detection of recombination as low as 7\%, the complete absence of Al sensitive recombinants suggests that tolerance in these cultivars is most probably, controlled by the same gene. Thus, the potential for improving Al tolerance through recombination of these genotypes is very low and different gene sources should be evaluated.
\end{abstract}

Index terms: Hordeum vulgare, genotypes, genetic inheritance, toxicity.

\section{Análise genética da tolerância ao alumínio em cevadas brasileiras}

Resumo - A toxicidade do alumínio (Al) é um dos principais limitantes ao crescimento da cevada em solos ácidos, e são necessários genótipos com adequada tolerância para melhorar a adaptação da espécie no Brasil. Para estudar a herança da tolerância ao Al em cevadas brasileiras, as cultivares Antarctica 1, BR 1 e FM 404 foram cruzadas com Kearney e PFC 8026 e intercruzadas entre si. Progenitores e gerações $F_{1}, F_{2}$ e $F_{6}$ foram cultivados em solução nutritiva contendo 0,03, 0,05 e 0,07 mM de Al, e classificadas quanto à tolerância, pelo método de coloração com hematoxilina. As progênies $\mathrm{F}_{2}$, das cruzas tolerante x suscetível, segregaram na proporção de três tolerantes para uma suscetível, enquadrando-se na proporção 3:1 esperada no modelo monogênico. As populações $F_{6}$ segregaram uma tolerante para uma suscetível, enquadrando-se no modelo de um gene. Nos cruzamentos entre tolerantes, as $\mathrm{F}_{2}$ apresentaram reação igual à dos progenitores. Como o tamanho de população usado permitiria detectar recombinações de 7\% na hipótese de mais de um gene ligados em repulsão, a ausência completa de segregantes suscetíveis sugere que a tolerância destas cultivares seja condicionada pelo mesmo gene. Desta maneira, o potencial para melhoria da tolerância ao Al por meio da recombinação destas cultivares é muito baixo, e devem ser pesquisadas fontes diferentes.

Termos para indexação: Hordeum vulgare, genótipos, herança genética, toxicidade.

\section{Introduction}

Soil acidity and aluminum toxicity have limited barley production in important world agricultural ar-

\footnotetext{
(1) Accepted for publication on November 22, 2001.

(2) Embrapa-Centro Nacional de Pesquisa de Trigo, Caixa Postal 451, CEP 99001-970 Passo Fundo, RS, Brazil. E-mail: eminella@cnpt.embrapa.br

(3) Cornell University, Dep. of Plant Breeding and Biometry, Ithaca, NY 114853-1902, USA. E-mail: mes12@cornell.edu
}

eas. Aluminum toxicity inhibits root cell division and elongation, thus reducing water and nutrient uptake and grain yield (Reid, 1971; Alam, 1981; Foy, 1983). Reduced drought tolerance, winter hardiness, and disease resistance have been indirectly associated with Al toxicity (Foy, 1984; Krizek \& Foy, 1988).

In Brazil, where toxic levels of $\mathrm{Al}$ occur in over half of the agricultural areas (Iturri Larach \& Camargo, 1976), barley production is limited to limed soils. Liming is costly and limited to the soil surface layer. Therefore, some level of genetic tolerance to toxic 
levels of $\mathrm{Al}$ is of great importance for barley production in Brazil and in other acid soil regions.

Barley cultivars and lines that tolerate toxic levels of $\mathrm{Al}$ or low soil $\mathrm{pH}$ have been reported (Foy et al., 1965; Slootmaker \& Arzadun, 1969; Reid, 1976; Ben et al., 1988; Minella \& Sorrells, 1992). According to Reid et al. (1980), over $200 \mathrm{Al}$ tolerant barley genotypes have already been reported and additional sources are likely, since only a small fraction of the world germplasm has been evaluated. The sources of tolerance include two and six-rowed barleys of both winter and spring habit, originating in Asia, Europe and America.

Although quantitative and complex, tolerance to low soil $\mathrm{pH}$ or aluminum toxicity is a simply inherited trait (Reid, 1971; Stølen \& Andersen, 1978; Minella, 1989). Stølen \& Andersen (1978) found a single gene $(P h t)$ explaining most of the differences for low soil $\mathrm{pH}$ tolerance in a group of spring barleys. Reid (1971) reported a single gene (Alp) controlling aluminum tolerance in winter cultivars Dayton and Smooth Awn 86. A single gene controlling tolerance in Dayton was confirmed by Minella \& Sorrells $(1992,1997)$. Theoretically, Pht and Alp could be the same gene, but the lack of relevant information in the studies performed prevent the establishment of their relationship. Pht and Alp were located on chromosome 4 by simple trait association (Stølen \& Andersen, 1978), trisomic analysis (Minella \& Sorrels, 1997) and molecular marker linkage analysis (Tang et al., 2000). Tolerance was dominant in all published studies, but shifted from dominant to recessive as Al concentration increased (Minella \& Sorrells, 1992), suggesting that it is a gene dosage-dependent trait in barley. Minor gene effects also have been postulated to explain discrepancies between observed and expected ratios for a single gene hypothesis (Reid, 1971; Minella, 1989). Minella \& Sorrells (1992) attributed the range of variation among barley cultivars to a single locus, with different alleles conferring different degrees of tolerance to aluminum.

The objective of this work was to study the inheritance of $\mathrm{Al}$ tolerance of barley cultivars developed under acid and $\mathrm{Al}$ toxic soil conditions in Brazil, their genetic relationship and their value for further improvement of this trait.

\section{Material and Methods}

\section{Genetic material}

The parental genotypes studied are listed on Table 1. The parental genotypes were previously classified for Al tolerance through the scale of Polle et al. (1978), based on their array of hematoxylin stainability scores at the 0.03 , 0.06 and $0.09 \mathrm{mM} \mathrm{Al} \mathrm{levels} \mathrm{(Minella,} \mathrm{1989).}$

The two-rowed spring barleys Antarctica 1, BR 1 and FM 404, represent the most Al tolerant germplasm developed in Brazil (Ben et al., 1988; Minella, 1989). They are pure line selections from Volla, W 5586 and Wisa WB, respectively. Breeding lines W 5586 and Wisa WB were developed by Weibull's in Brazil. Most probably, the ancestral donors of $\mathrm{Al}$ tolerance in these genotypes are $\mathrm{Ba}$ varia through Volla, Gull through Kenia and Ciho 959 through Wisa WB, respectively (Minella, 1989). Kearney, a six-rowed winter barley from USA and PFC 8026, a spring two-rowed derivative of TR 207 from Canada, were used as the $\mathrm{Al}$ sensitive parents (Foy et al., 1965; Minella \& Sorrells, 1992). Parental and hybrid $F_{1}, F_{2}$ and generations derived from tolerant by sensitive and tolerant by tolerant crosses were used for the genetic analysis. The $\mathrm{F}_{6}$ populations were obtained through the Single Seed Descent method.

\section{Screening technique}

The hematoxylin staining method of Polle et al. (1978) was chosen because it has given results consistent with root measurements (Takagi et al., 1981; Carver et al., 1988), and has been used in genetic studies and in wheat breeding programs (Carver et al., 1988).

The response of all genotypes to $\mathrm{Al}$ was assayed by the hematoxylin staining procedure developed by Polle et al. (1978) with some modifications (Minella, 1989). Seeds were presoaked in distilled water for 12 hours and planted in cone-shaped cells of styrofoam trays. Each tray contained 104 cells measuring $1.5 \mathrm{~cm}$ in diameter and $4.5 \mathrm{~cm}$ in height. The bottom of the tray was covered with a nylon screen, secured with silicone glue. The trays float,

Table 1. Pedigree and Al tolerance classification of the parental genotypes analysed.

\begin{tabular}{llc}
\hline Genotype & Pedigree & $\mathrm{Al}^{(1)}$ \\
\hline Antarctica 1 & Selection of Volla & $\mathrm{T}$ \\
BR 1 & Binder/Opal//Balder/Kenia & $\mathrm{T}$ \\
FM 404 & Selection of Wisa WB & $\mathrm{T}$ \\
Kearney & Selection of CC XIII & $\mathrm{S}$ \\
PFC 8026 & Selection of TR 207 & $\mathrm{S}$ \\
\hline
\end{tabular}

${ }^{(1)} \mathrm{Al}$ classes: T: tolerant; S: sensitive (Minella, 1989). 
eliminating the need for suspending them over the surface of the solution. Imbibed seeds were allowed to germinate in the growth chamber until the radicle completely emerged. After radicle emergence, the trays were put for 24 hours in plastic containers containing a nutrient solution of the following composition: $4 \mathrm{mM} \mathrm{CaCl}_{2}, 6.5 \mathrm{mM} \mathrm{KNO}_{3}, 2.5 \mathrm{mM}$ $\mathrm{MgCl}_{2}, 0.1 \mathrm{mM}\left(\mathrm{NH}_{4}\right)_{2} \mathrm{SO}_{4}$, and $0.4 \mathrm{mM} \mathrm{NH} \mathrm{NO}_{3}$. Approximately $20 \mathrm{~mL}$ of nutrient solution per seedling was maintained in the container throughout the experiments. Seedlings were then grown for 30 hours in the above nutrient solution with the $\mathrm{pH}$ adjusted to 4.0 with $0.1 \mathrm{M} \mathrm{HCl}$ solution. Throughout the experiments, plants were grown at a constant temperature of $22^{\circ} \mathrm{C}$ with a 12 hour photoperiod until placed in the $\mathrm{Al}$ solutions. Seedlings were then grown for 17 hours under light at $25^{\circ} \mathrm{C}$ and $\mathrm{pH} 4.0$ in nutrient solution with $\mathrm{Al}$ added from a $0.1 \mathrm{M} \mathrm{AlCl}_{3} \cdot 6 \mathrm{H}_{2} \mathrm{O}$ stock solution. Final Al concentrations used were 0.03, $0.05,0.06$ and $0.07 \mathrm{mM}$. Seedling roots were then rinsed and the trays placed in distilled water. One hour later the trays were put into a container with $0.5 \mathrm{~L}$ of a $0.2 \%(\mathrm{w} / \mathrm{v})$ hematoxylin staining solution for 15 minutes. Roots were washed and returned to distilled water for 30 minutes before scoring. Root tips were scored for the degree of staining after the seedlings were transferred to plastic trays lined with moistened white paper and covered with clear plastic film. Scoring was based on the pattern of staining of the primary root tip. At each $\mathrm{Al}$ level, the $\mathrm{F}_{2}$ screening included parents and $\mathrm{F}_{1}$ genotypes assigned randomly to four of the 104 cells of each tray. Except for the $F_{2}$, each genotype was represented by three seedlings per cell. Three $\mathrm{F}_{2}$ seeds were randomly assigned to each of the 100 remaining cells. Each $\mathrm{F}_{6}$ was tested in a completely randomized design with two replications for each Al level. The response of parental and progeny genotypes to $\mathrm{Al}$ was classified according to the degree of stainability by hematoxylin of the root tip grown during the Al stress period. At each Al level, a genotype was scored as complete (C), partial $(\mathrm{P})$ or non $(\mathrm{N})$ stained. A genotype was considered tolerant at a particular Al level if scored either $\mathrm{N}$ or $\mathrm{P}$.

\section{Genetic analysis}

The mode of inheritance and the relationship among the tolerant parents was assessed by the chi-square analysis of the observed ratios of N:P:C, N+P:C and P:C in the hybrid populations derived from crosses within and between tolerant classes. The chi-square values for a ratio observed at different $\mathrm{Al}$ levels within a cross and in different crosses with a parent in common were tested for homogeneity by computing a chi-square value for additivity according to Gomez \& Gomez (1984). The recombination values between two genes linked in repulsion that could have been detected with the sample size utilized was estimated by determining the minimum number of genotypes to recover at least one $\mathrm{Al}$ sensitive recombinant genotype. The minimum population size required at the 0.95 probability level was determined by the equation:

$\mathrm{n}=\log \mathrm{P}_{0.05} / \log (1-\mathrm{P})$

where $\mathrm{n}$ is the sample size, $\mathrm{P}_{0.05}$ is the chance probability of not obtaining at least one sensitive recombinant, and $\mathrm{P}$ is the expected frequency of the target genotype. For any generation, the expected frequency of the recombinant $\mathrm{Al}$ sensitive genotype (aabb) was calculated by the recurrence equations of Haldane \& Waddington (1931), for recombination value $p$ between 0 and 0.5 . The estimate of $p$ was the p-value in the recurrence equations that would result in a genotypic frequency $(\mathrm{P})$ that in turn would result in a calculated $\mathrm{n}$ approximately equal to the sample size used.

\section{Results and Discussion}

\section{Tolerant $x$ sensitive crosses}

Antarctica 1, BR 1 and FM 404 scored as N, P and $\mathrm{C}$ at the $0.03,0.05$ and $0.07 \mathrm{mM}$ Al levels used throughout the screenings, whereas Kearney and PFC 8026 scored as C.

The $F_{1}$ seedlings of all crosses scored the same as the tolerant parent at the 0.03 and $0.05 \mathrm{mM} \mathrm{Al}$ levels, and similar to the sensitive parent at the $0.07 \mathrm{mM}$ level suggesting that gene or allele dose becomes important above a threshold level of aluminum.

The $F_{2}$ populations showed no segregation for the pattern of the root tip hematoxylin staining at the $0.03 \mathrm{mM}$, and segregated into the two parental staining classes at the $0.05 \mathrm{mM} \mathrm{Al}$ level, respectively (Table 2). At the $0.03 \mathrm{mMAl}$, the $\mathrm{F}_{2}$ segregated three tolerant $(\mathrm{N})$ to one sensitive $(\mathrm{C})$, fitting the ratio $\left(\mathrm{P} \geq \chi^{2}=0.838,0.846\right.$ and 0.610 , respectively for Antarctica 1, BR 1 and FM 404) for a single gene difference with complete dominance of the non-staining reaction $(\mathrm{N})$. The segregation at the $0.05 \mathrm{mM} \mathrm{Al}$ was also three tolerant $(\mathrm{P})$ to one sensitive $(\mathrm{C})$ for the three crosses with Kearney. When tested at $0.06 \mathrm{mM}$ $\mathrm{Al}$, the BR 1/Kearney $\mathrm{F}_{2}$ segregated one tolerant $(\mathrm{P})$ to three sensitive $(\mathrm{C})$ ratio, indicating that the seedlings heterozygous for the $\mathrm{Al}$ reaction expressed the same reaction as the sensitive parent, and tolerance 
Table 2. Hematoxylin staining class frequency of the $\mathrm{F}_{2}$ and $\mathrm{F}_{6}$ derived from tolerant versus sensitive crosses at different levels of aluminum.

\begin{tabular}{|c|c|c|c|c|c|c|c|}
\hline \multirow[t]{2}{*}{ Cross } & \multirow{2}{*}{$\begin{array}{c}\mathrm{Al} \\
(\mathrm{mM})\end{array}$} & \multicolumn{4}{|c|}{ Staining class frequency ${ }^{(1)}$} & \multirow[t]{2}{*}{$\chi^{2(2)}$} & \multirow{2}{*}{$\begin{array}{l}\text { Prob. of a } \\
\text { greater } \chi\end{array}$} \\
\hline & & $\mathrm{N}$ & $\mathrm{P}$ & $\mathrm{C}$ & Total & & \\
\hline \multicolumn{8}{|c|}{$\mathrm{F}_{2}$ generation } \\
\hline BR 1/Kearney & 0.03 & 240 & 0 & 78 & 318 & 0.380 & 0.8460 \\
\hline BR 1/Kearney & 0.05 & 0 & 179 & 57 & 236 & 0.090 & 0.7637 \\
\hline BR 1/Kearney & 0.06 & 0 & 54 & 166 & 220 & 0.024 & 0.8763 \\
\hline FM 404/Kearney & 0.03 & 166 & 0 & 51 & 217 & 0.260 & 0.7104 \\
\hline FM 404/Kearney & 0.05 & 0 & 110 & 39 & 149 & 0.110 & 0.7406 \\
\hline Antarctica $1 /$ Kearney & 0.03 & 152 & 0 & 49 & 201 & 0.040 & 0.8387 \\
\hline Antarctica $1 /$ Kearney & 0.05 & 0 & 150 & 48 & 198 & 0.061 & 0.8055 \\
\hline \multicolumn{8}{|c|}{$\mathrm{F}_{6}$ generation } \\
\hline Antarctica 1/PFC 8026 & 0.05 & 0 & 31 & 33 & 64 & 0.062 & 0.8026 \\
\hline FM 404/PFC 8026 & 0.05 & 0 & 46 & 48 & 94 & 0.043 & 0.8366 \\
\hline
\end{tabular}

(1)N: no staining (tolerant); P: partial staining (tolerant); C: complete staining (sensitive). (2) $3: 1$ or $1: 3$ for the $\mathrm{F}_{2}$ and $1: 1$ for the $\mathrm{F}_{6}$.

(P) was recessive at that $\mathrm{Al}$ level. Heterozygous genotypes, thus, were very sensitive to any increase of $\mathrm{Al}$ above a threshold value.

The $\mathrm{F}_{2}$ derived $\mathrm{F}_{6}$ populations for the crosses with PFC 8026 segregated in an one tolerant to one sensitive (1:1) at the $\mathrm{Al}$ level tested, fitting the ratio expected for a single gene model $\left(\mathrm{P} \geq \chi^{2}=0.802\right.$ and 0.836 , respectively) (Table 2).

The results obtained in this analysis confirm those of Reid (1971), Minella \& Sorrells $(1992,1997)$ and Tang et al. (2000) of single gene controlling Al tolerance in barley.

\section{Tolerant $\mathrm{x}$ tolerant crosses}

The hematoxylin staining class frequencies for the crosses among the tolerant parents showed no indication of segregation for any cross and Al level (Table 3). The failure to detect completely stained (C) seedlings at the Al levels where parents were partially $(\mathrm{P})$ or non-stained $(\mathrm{N})$, indicates that tolerance in these genotypes is either controlled by the same locus or by tightly linked loci. Transgressive segregates more tolerant than the parents were not observed at 0.05 and $0.07 \mathrm{mM} \mathrm{Al}$, indicating either the absence of new gene combinations or that different genes were not additive in their effects. If the $\mathrm{F}_{2}$ populations from all crosses were combined, then the sample size used would allow detection of $7 \%$ to $8 \%$ recombination. The $\mathrm{F}_{6}$ populations used would allow detection of recombination values between 3.5
Tabela 3. Hematoxylin staining class frequency at three Al concentrations for the $\mathrm{F}_{2}$ from crosses among tolerant genotypes.

\begin{tabular}{crrrr}
\hline $\begin{array}{c}\text { Aluminum } \\
(\mathrm{mM})\end{array}$ & \multicolumn{5}{c}{ Hematoxylin staining class frequency ${ }^{(1)}$} \\
\cline { 2 - 5 } & $\mathrm{N}$ & $\mathrm{P}$ & $\mathrm{C}$ & Total \\
\hline \multicolumn{5}{c}{ FM 404 x BR 1 } \\
0.03 & 193 & 0 & 0 & 193 \\
0.05 & 0 & 209 & 0 & 209 \\
0.07 & 0 & 0 & 196 & 196 \\
\hline \multicolumn{5}{c}{ Antarctica 1 x BR 1 } \\
0.03 & 295 & 0 & 0 & 295 \\
0.05 & 0 & 220 & 0 & 220 \\
0.07 & 0 & 0 & 189 & 189 \\
\hline \multicolumn{5}{c}{ FM 404 x Antarctica 1 } \\
0.03 & 205 & 0 & 0 & 205 \\
0.05 & 0 & 180 & 0 & 180 \\
0.07 & 0 & 0 & 240 & 240 \\
\hline \multicolumn{5}{c}{}
\end{tabular}

${ }^{(1)} \mathrm{N}$ : no staining (tolerant); P: partial staining (tolerant); C: complete staining (sensitive).

and $5.5 \%$. These results suggest that the hypothesis of different linked loci controlling tolerance in these genotypes is unlikely.

\section{Conclusions}

1. The Al tolerance level of Antarctica 1, BR 1 and FM 404 is controlled by a single dominant gene.

2 . The lack of segregation in hybrids from these genotypes suggests that they all carry the same gene for tolerance. 
3. The possibility of major improvement of Al tolerance through recombination of these genotypes is remote.

\section{References}

ALAM, S. M. Influence of aluminum on plant growth and mineral nutrition of barley. Communications in Soil Science Plant Analysis, New York, v. 12, p. 121-138, 1981.

BEN, J. R.; PERUZZO, G.; MINELLA, E. Comportamento de alguns genótipos de cevada em relação à acidez do solo. Pesquisa Agropecuária Brasileira, Brasília, v. 23, n. 11, p. 1315-1320, nov. 1988.

CARVER, B. F.; INSKEEP, W. P.; WILSON, N. P.; WESTERMAN, R. L. Seedling tolerance to aluminum toxicity in hard red winter wheat germplasm. Crop Science, Madison, v. 28, p. 1463-1467, 1988.

FOY, C. D. Physiological effects of hydrogen, aluminum and manganese toxicities in acid soil. In: ADAMS, F. (Ed.). Soil acidity and liming. 2. ed. Madison: American Society of Agronomy, 1984. p. 57-97. (Agronomy, 12).

FOY, C. D. The physiology of plant adaptation to mineral stress. Iowa State Journal of Research, Ames, v. 57, p. 355-391, 1983.

FOY, C. D.; ARMIGER, W. H.; BRIGGLE, L. W.; REID, D. A. Aluminum tolerance of wheat and barley varieties. Agronomy Journal, Madison, v. 57, p. 413-417, 1965.

GOMEZ, K. A. A.; GOMEZ, A. A. Statistical procedures for agricultural research. New York: J. Wiley, 1984. $374 \mathrm{p}$.

HALDANE, J. B. S.; WADDINGTON, C. H. Inbreeding and linkage. Genetics, Bethesda, v. 16, p. 357-374, 1931.

ITURRI LARACH, J. O.; CAMARGO, M. N. Aluminum toxicity in Brazilian soils: characterization and distribution. Ciência e Cultura, São Paulo, v. 28. p. 171-180, 1976.

KRIZEK, D. T.; FOY, C. D. Role of water stress in differential aluminum tolerance in two barley cultivars grown in an acid soil. Journal of Plant Nutrition, New York, v. 11, p. 351-367, 1988.

MINELLA, E. Aluminum tolerance in barley: inheritance, chromosome location, genetic relationships of sources of diverse origins and breeding implications. $1989.70 \mathrm{p}$. Dissertation (Ph.D.) - Cornell University, Ithaca.

MINELLA, E.; SORRELLS, M. E. Aluminum tolerance in barley: genetic relationships among genotypes of diverse origin. Crop Science, Madison, v. 32, p. 593-598, 1992.

MINELLA, E.; SORRELLS, M. E. Inheritance and chromosome location of Alp: a gene controlling aluminum tolerance in 'DAYTON' barley. Plant Breeding, Berlin, v. 116, p. 465-469, 1997.

POLLE, E.; KONZAK, C. F.; KITTRICK, J. A. Visual detection of aluminum tolerance levels in wheat by hematoxylin staining of seedling roots. Crop Science, Madison, v. 18 , p. 823-827, 1978.

REID, D. A. Genetic control of reaction to aluminum in winter barley. In: INTERNATIONAL BARLEY GENETICS SYMPOSIUM, 2., 1971, Pullman. Proceedings... Pullman: Washington State University Press, 1971. p. 409-413.

REID, D. A. Genetic potential for solving problems of soil mineral stress: aluminum and manganese toxicities in cereal grains. In: WRIGHT, M. J. (Ed.). Plant adaptation to mineral stress in problem soils. Ithaca: Cornell University Press, 1976. p. 55-64.

REID, D. A.; SLOOTMAKER, L. A. J.; STØLEN, O.; CRADDOCK, C. Registration of barley composite cross XXXIV. Crop Science, Madison, v. 20, p. 416-417, 1980.

SLOOTMAKER, L. A. J.; ARZADUN, J. F. Selection of young barley plants to high soil acidity in relation to some agronomic characteristics of mature plants. Euphytica, Dordrecht, v. 18, p. 157-162, 1969.

STØLEN, O.; ANDERSEN, S. Inheritance of tolerance to low soil pH in barley. Hereditas, Lund, v. 88, p. 101-105, 1978.

TAKAGI, H.; NAMAI, H.; MURAKAMY, K. Evaluation of the hematoxylin staining method for detecting wheat tolerant to aluminum. Japanese Journal of Breeding, Tokyo, v. 31, p. 152-160, 1981.

TANG, Y.; SORRELLS, M. E.; KOCHIAN, L. V.; GARVIN, D. F. Identification of RLFP markers linked to the barley aluminum tolerance gene Alp. Crop Science, Madison, v. 40, p. 778-782, 2000. 